\title{
Relationship of selected sociodemographic factors and body composition in an open population of Rzeszów inhabitants participating in a health promoting event
}

\begin{abstract}
Introduction. The structure of the human body may vary greatly, depending on a number of factors, sociodemographic ones in particular. An analysis of the body composition makes it possible to assess the existing differences and provides broader insight into the multidimensional changes occuring to the human body.

Aim. An investigation of the relationship between selected sociodemographic factors and body composition in an open population of Rzeszów residents.

Material and methods. The study was performed on a group of 101 adults, aged 30-83. Their body composition was examined using bioimpedance analyzer BIA-101 and selected sociodemographic factors were investigated using a survey questionnaire designed for that particular purpse. Mann-Whitney U test and Kruskal-Wallis test were applied to identify statistically significant differences between the examined variables. Additionally, Spearman's rho correlation coefficient was applied. The study adopted a significance level of $p<0.05$. Calculations were performed using IBM SPSS Statistics 20 .

Results. The findings revealed some significant differences $(\mathrm{p}<0.05)$ related to gender, age and employment status, as well as selected constituents of fat mass and fat free mass in the subjects.

Conclusions. Selected sociodemographic factors significantly affect the components of body composition in adults. Further longitudinal studies are needed to confirm the reported differences.
\end{abstract}

Keywords: sociodemographic factors, body composition, bioelectrical impedance, adults.

DOI: $10.1515 /$ pjph-2016-0014

\section{INTRODUCTION}

The model structure of the human body is derived from post-mortem chemical analyses of the body. Results of measurements performed with indirect methods are based on certain computational assumptions, yet they are subject to some significant limitations. The most common theoretical model of human body structure is the two compartment one, which distinguishes fat mass (FM) and fat free mass (FFM) in the body. Currently, an easy identification of the specific components of body composition using the three compartment model (FM fat mass, TBW - total body water, LFFM - lean fat free mass) or four compartment model (FM, TBW, protein mass, bone or mineral mass) is possible. The latter is recognized as the "golden standard" for body composition assessment [1].

In humans, fat accounts for some $10-20 \%$ of the body weight. Lean body mass (LBM) constitutes approx. 70-85\%, out of which connective tissue and bones constitute approx. $15 \%[2]$.

Body composition changes occur with different dynamics at various stages of life. There are visible differences related to selected indexes and specific components in populations of healthy individuals $[3,4]$. During childhood and youth, some rapid growth in lean body mass can be observed - it usually reaches its maximum by the age of 20-25 in men, and 16-19 in women. Subsequently, there is a noticeable increase in adipose tissue in adults of both sexes, yet it is more pronounced in women. Adipose tissue is accumulated with varied intensity depending on such factors as one's dietary habits and physical activity. Furthermore, a gradual process of regression affects the mass of tissues involved in metabolic activity. At older age, this process is masked by growth of adipose tissue and connective tissue growing mainly over muscle mass [2,5].

Numerous factors differentiating the human population may impact changes in the body composition. Adiposity level might be affected by age, gender, lifestyle, level of physical activity, body-build and ethnicity as well as the type of equipment examining body composition [3,6-9]. Given the above, studies involving various groups of subjects seem to be extremely interesting.

\section{AIM}

This study was designed to assess the relationship between selected sociodemographic factors and body composition in an open population of Rzeszów residents. 


\section{MATERIAL AND METHODS}

During a two-day health promotion event named Festival of Health in the Heart of the City held in Rzeszów, designed to promote healthy lifestyle and to prevent diseases of affluence, a few hundred guests had a non-invasive anthropometric examination performed on them. There were some individuals who refused to give their consent and they were obviously excluded from receiving examination, as well as people with the following symptoms: signs of circulatory failure (visible peripheral oedema), pregnant women, and with selfreported health problems: kidney failure, cardiac pacemaker, epilepsy. A health-check stand was set up where the subjects were examined for their height, body mass and body composition (BIA). A total of 167, aged 30-86 were examined and the statistical analyses were performed for the scores of 101 subjects aged 30-83 years, all residents of Rzeszów. The measurements were performed by a person with medical background, both in terms of relevant education and experience using the equipment. Both body mass and height were measured using the SECA 799 scale equipped with telescopic measuring rod. Body composition measurements were carried out using impedance analyser BIA-101 manufactured by AKERN (Italy). The measurement was performed using tetrapolar system in a contralateral arrangement (amplitude of the measuring current $800 \mathrm{uA}$, sinusoidal, $50 \mathrm{kHz}$ ), in the morning hours $(7.00$ $12.00)$, in supine position, with abduction of upper $\left(30^{\circ}\right)$ and lower limbs $\left(45^{\circ}\right)$, after 5 -minute rest. In order to ensure the high reliability of the results, the measurements were conducted twice (one after another). Disposable electrodes were placed on the dorsal surface of the right upper limb (above the cavity of the wrist joint), and the right lower limb (ankle joint). The above precision in preparing the patient and the measurement of resistance and reactance is in compliance with the instructions of the equipment manufacturer and recommendations of many researchers [10].

The results of the measurements were transferred to specialist software (Bodygram1_31 from AKERN) in order to compute the following parameters: fat mass (FM), fat free mass (FFM), body cell mass (BCM) and muscle mass (MM). The equations used in the software to assess the specific parameters are restricted property of the company, but to a significant degree they are based on computing algorithms developed by Sun S.[11].

The study was conducted in compliance with the Declaration of Helsinki, and it was approved by the Bioethics Commission at the University of Rzeszów.

During the analyses, some differences were verified using both the Mann-Whitney's test (comparison of two categories) and Kruskal-Wallis' test (comparing more than two categories). In case of the latter test, the statistically significant differences were subject to additional examination using Dunn's test (pairwise comparison) to show which pairs of categories significantly differed between one another. Spearman's rank correlation coefficient (Spearman's rho) was applied. The study adopted the significance level $p<0.05$. Calculations were performed with IBM SPSS Statistics 20.

\section{RESULTS}

A statistical analysis of 101 adults aged 30-83 (mean age of the subjects 60.98 years, standard deviation $\mathrm{SD}=11.95$ ), all residents of Rzeszów. Most subjects were retired individuals
(63.0\% - 58 people), employed (20.7\%), and unemployed (7.6\%). More than a half of the subjects were female $(66.3 \%)$, and individuals in married or steady relationship (71.1\%). Nearly a half of the subjects (48.9\%) had secondary education. The group reported the following health status: good health (38.2\% - 38 individuals), hypertension (41.6\%) and other chronic conditions (22.8\% - diabetes, atherosclerosis, varicose veins).

The mean contents of cell mass (BCM) in the subjects was $25.49 \mathrm{~kg}(\mathrm{SD}=6.14)$. The values ranged from 16.5 to $41.8 \mathrm{~kg}$, and in half of the subjects the BCM was below $23.9 \mathrm{~kg}$. The mean contents of fat free mass (FFM) in the subjects was $49.59 \mathrm{~kg}$ $(\mathrm{SD}=10.02)$. The minimum and maximum values ranged between $35.9 \mathrm{~kg}$ to $81.2 \mathrm{~kg}$ and half of the subjects had FFM below $45.9 \mathrm{~kg}$. Average fat mass (FM) in the study group was $24.82 \mathrm{~kg}(\mathrm{SD}=9.87)$. The results ranged from 6.4 to $54.1 \mathrm{~kg}$, and half of the subjects had FM below $22.8 \mathrm{~kg}$. On average, the muscle mass $(\mathrm{MM})$ amounted to $31.76 \mathrm{~kg}(\mathrm{SD}=7.33)$. The results ranged between 21.4 and $50.7 \mathrm{~kg}$ but in half of the subjects the MM was below $29.7 \mathrm{~kg}$.

The present findings showed that the age significantly affected the body composition in the subjects. It was observed that younger individuals had significantly higher values of fat free mass (FFM) than older subjects (Figure 1). An analysis of the measurements also showed that fat mass (FM) significantly increased with the subjects' age (Figure 2).

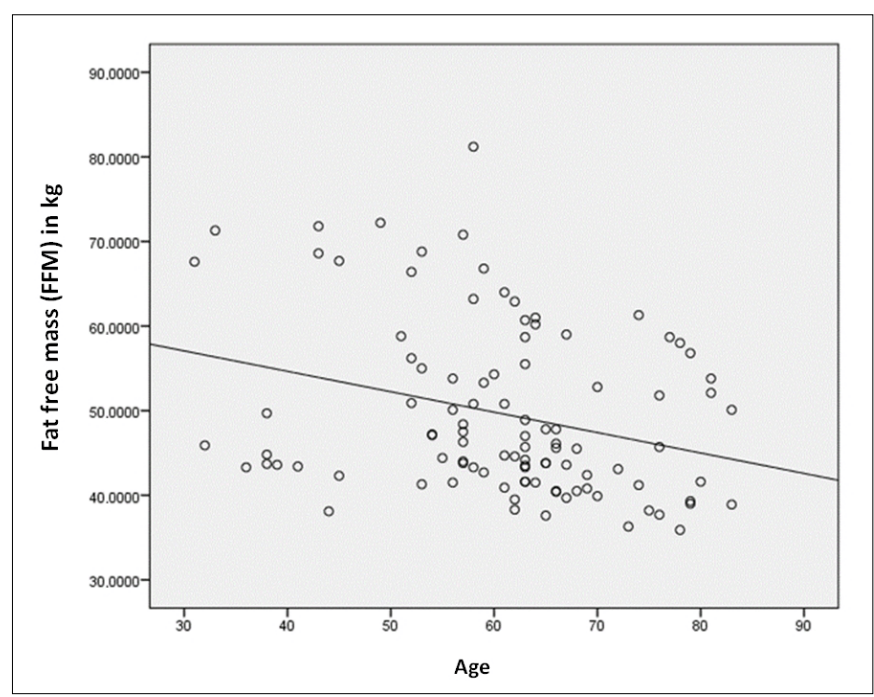

FIGURE 1. Fat-free mass (FFM) in kg vs. the subjects age.

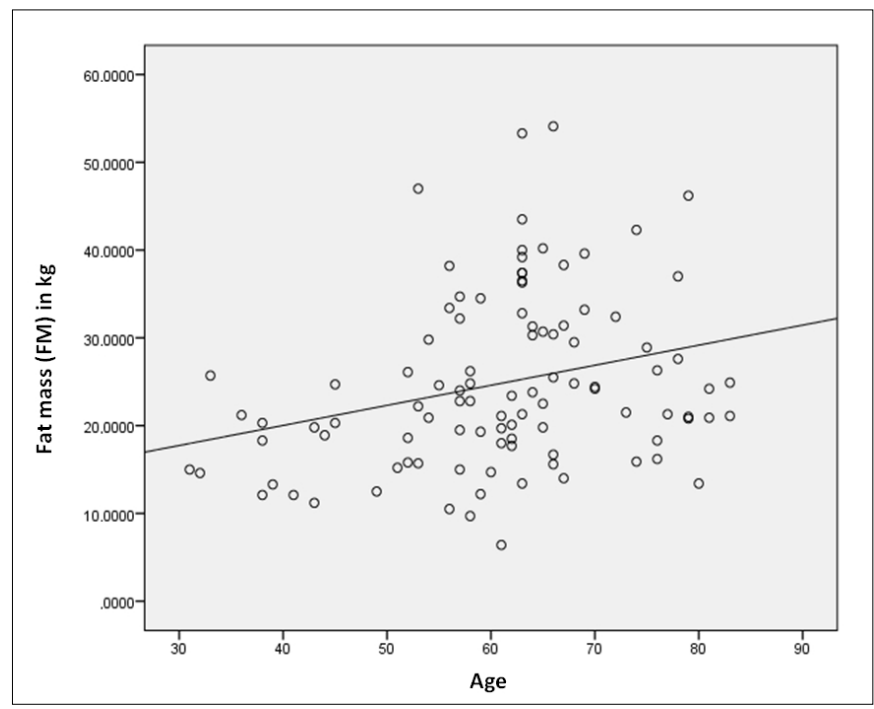

FIGURE 2. Fat mass (FM) in kg vs. the subjects' age. 
TABLE 1. Body composition vs. the subjects' age.

\begin{tabular}{|c|c|c|c|c|c|c|c|c|c|}
\hline \multicolumn{2}{|c|}{ Gender } & BCM & $\begin{array}{c}\text { BCM } \\
\%\end{array}$ & FFM & $\begin{array}{c}\text { FFM } \\
\%\end{array}$ & FM & $\begin{array}{l}\text { FM } \\
\%\end{array}$ & ММ & $\begin{array}{c}\text { MM } \\
\%\end{array}$ \\
\hline \multirow{6}{*}{$\begin{array}{l}\stackrel{0}{\widetilde{\Xi}} \\
\stackrel{\Xi}{\rightleftarrows}\end{array}$} & M & 22.34 & 50.54 & 44.10 & 63.24 & 26.77 & 36.73 & 27.89 & 39.79 \\
\hline & $\mathrm{N}$ & 67 & 67 & 67 & 67 & 67 & 67 & 66 & 66 \\
\hline & SD & 3.22 & 3.85 & 4.53 & 7.93 & 9.56 & 7.94 & 3.72 & 5.47 \\
\hline & $\mathrm{Me}$ & 22.00 & 50.80 & 43.60 & 63.20 & 24.90 & 36.80 & 27.50 & 38.90 \\
\hline & Min & 16.50 & 41.90 & 35.90 & 46.90 & 9.70 & 18.20 & 21.40 & 30.00 \\
\hline & Max & 29.20 & 58.50 & 55.50 & 81.80 & 54.10 & 53.10 & 36.10 & 53.80 \\
\hline \multirow{6}{*}{$\frac{\stackrel{0}{\widetilde{J}}}{\Xi}$} & M & 31.71 & 52.35 & 60.40 & 74.85 & 20.99 & 25.15 & 39.28 & 48.63 \\
\hline & $\mathrm{N}$ & 34 & 34 & 34 & 34 & 34 & 34 & 34 & 34 \\
\hline & SD & 5.77 & 3.61 & 9.04 & 7.87 & 9.49 & 7.87 & 6.78 & 6.25 \\
\hline & $\mathrm{Me}$ & 32.30 & 52.50 & 60.45 & 75.65 & 20.20 & 24.35 & 39.95 & 49.05 \\
\hline & Min & 21.50 & 45.80 & 41.50 & 52.40 & 6.40 & 11.20 & 26.60 & 34.00 \\
\hline & Max & 41.80 & 58.60 & 81.20 & 88.80 & 53.30 & 47.60 & 50.70 & 59.30 \\
\hline \multirow{6}{*}{ 苞 } & M & 25.49 & 51.15 & 49.59 & 67.15 & 24.82 & 32.83 & 31.76 & 42.79 \\
\hline & $\mathrm{N}$ & 101 & 101 & 101 & 101 & 101 & 101 & 100 & 100 \\
\hline & SD & 6.14 & 3.85 & 10.02 & 9.61 & 9.87 & 9.61 & 7.33 & 7.10 \\
\hline & $\mathrm{Me}$ & 23.90 & 51.50 & 45.90 & 66.80 & 22.80 & 32.90 & 29.70 & 42.45 \\
\hline & Min & 16.50 & 41.90 & 35.90 & 46.90 & 6.40 & 11.20 & 21.40 & 30.00 \\
\hline & Max & 41.80 & 58.60 & 81.20 & 88.80 & 54.10 & 53.10 & 50.70 & 59.30 \\
\hline $\mathrm{p}$ & & $<0.001$ & 0.032 & $<0.001$ & $<0.001$ & 0.002 & $<0.001$ & $<0.001$ & $<0.001$ \\
\hline
\end{tabular}

$\mathrm{FM}$ - fat mass [kg], FFM - fat free mass [kg], BCM - body cell mass [kg], $\mathrm{MM}-$ muscle mass [kg], ${ }^{*} \mathrm{p}<0.05$

TABLE 2. Body composition vs. employment status.

\begin{tabular}{|c|c|c|c|c|c|c|c|c|c|}
\hline Gen & & ВCM & $\begin{array}{c}\text { BCM } \\
\%\end{array}$ & FFM & $\begin{array}{c}\text { FFM } \\
\%\end{array}$ & FM & $\begin{array}{l}\text { FM } \\
\%\end{array}$ & MM & $\begin{array}{c}\text { MM } \\
\%\end{array}$ \\
\hline \multirow{6}{*}{ 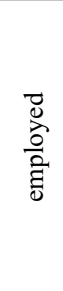 } & M & 31.86 & 54.82 & 57.96 & 72.67 & 21.61 & 27.21 & 39.06 & 48.99 \\
\hline & $\mathrm{N}$ & 17 & 17 & 17 & 17 & 17 & 17 & 17 & 17 \\
\hline & SD & 7.02 & 2.69 & 11.89 & 9.37 & 7.84 & 9.29 & 8.46 & 7.23 \\
\hline & $\mathrm{Me}$ & 33.20 & 55.50 & 58.80 & 75.60 & 20.30 & 24.40 & 40.50 & 50.30 \\
\hline & Min & 19.80 & 48.00 & 38.10 & 49.40 & 11.20 & 13.40 & 25.00 & 30.00 \\
\hline & Max & 41.80 & 58.60 & 72.20 & 86.60 & 42.30 & 50.60 & 50.70 & 59.20 \\
\hline \multirow{6}{*}{ 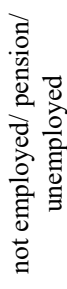 } & M & 26.75 & 51.90 & 51.47 & 71.44 & 21.11 & 28.56 & 33.39 & 45.90 \\
\hline & $\mathrm{N}$ & 26 & 26 & 26 & 26 & 26 & 26 & 25 & 25 \\
\hline & SD & 5.91 & 3.57 & 10.76 & 8.79 & 8.95 & 8.79 & 7.19 & 6.23 \\
\hline & $\mathrm{Me}$ & 26.35 & 51.95 & 50.25 & 71.50 & 20.60 & 28.50 & 32.50 & 45.50 \\
\hline & Min & 17.50 & 45.90 & 35.90 & 53.90 & 6.40 & 11.20 & 22.10 & 34.70 \\
\hline & Max & 38.50 & 57.70 & 81.20 & 88.80 & 47.00 & 46.10 & 48.20 & 59.30 \\
\hline \multirow{6}{*}{ 总 } & M & 23.07 & 49.73 & 46.28 & 63.61 & 27.43 & 36.39 & 28.92 & 39.64 \\
\hline & $\mathrm{N}$ & 58 & 58 & 58 & 58 & 58 & 58 & 58 & 58 \\
\hline & SD & 4.26 & 3.48 & 7.21 & 8.56 & 10.12 & 8.56 & 5.12 & 5.54 \\
\hline & $\mathrm{Me}$ & 22.30 & 50.40 & 43.90 & 62.45 & 24.85 & 37.55 & 27.85 & 38.85 \\
\hline & Min & 16.50 & 41.90 & 36.30 & 46.90 & 10.50 & 19.20 & 21.40 & 30.10 \\
\hline & Max & 35.70 & 55.80 & 64.00 & 80.80 & 54.10 & 53.10 & 43.70 & 53.30 \\
\hline \multirow{6}{*}{ 苞 } & M & 25.49 & 51.15 & 49.59 & 67.15 & 24.82 & 32.83 & 31.76 & 42.79 \\
\hline & $\mathrm{N}$ & 101 & 101 & 101 & 101 & 101 & 101 & 100 & 100 \\
\hline & SD & 6.14 & 3.85 & 10.02 & 9.61 & 9.87 & 9.61 & 7.33 & 7.10 \\
\hline & $\mathrm{Me}$ & 23.90 & 51.50 & 45.90 & 66.80 & 22.80 & 32.90 & 29.70 & 42.45 \\
\hline & Min & 16.50 & 41.90 & 35.90 & 46.90 & 6.40 & 11.20 & 21.40 & 30.00 \\
\hline & & 41.80 & 58.60 & 81.20 & 88.80 & 54.10 & 53.10 & 50.70 & 59.30 \\
\hline $\mathrm{p}$ & & $<0.001 *$ & $<0.001^{*}$ & $<0.001 *$ & $<0.001 *$ & $<0.001 *$ & $<0.001 *$ & $<0.001 *$ & $<0.001^{*}$ \\
\hline
\end{tabular}

$\mathrm{FM}$ - fat mass [kg], FFM - fat-free mass [kg], BCM - body cell mass [kg], $\mathrm{MM}-$ muscle mass $[\mathrm{kg}],{ }^{*} \mathrm{p}<0.05$
There were also statistically significant differences between the subjects' age and the values representing their body composition. The females were found to have a significantly lower mean value of cell mass (BCM) than males $(22.34 \mathrm{~kg}$ vs. $31.71 \mathrm{~kg})$. The same relationship was observed in the levels of fat free mass (FFM) (44.10 kg vs. $60.40 \mathrm{~kg}$ ). The group of females, on the other hand, was found with significantly higher mean fat mass $(26.77 \mathrm{~kg})$ compared to the males $(20.99 \mathrm{~kg})$. The men had significantly higher muscle mass $(39.28 \mathrm{~kg})$ than women $(27.89 \mathrm{~kg})$ (Table 1).

The present study showed statistically significant differences between the values representing body composition and subjects' professional status. Detailed values of body composition components and their relationships are shown in Table 2.

\section{DISCUSSION}

An analysis of the present findings provides evidence for numerous statistically significant differences in body composition of the examined adults. Young individuals were found to have considerably higher values of fat free mass compared with individuals at more advanced age. There was a direct relationship between fat mass increase and age. Irish researches investigating body composition changes in a population of some 1606 Irish (aged 18-81) made similar conclusions. The centile grids drawn by them for fat and fat free mass and the indexes of the above components are consistent with the present findings [3]. Interesting evidence was reported by researchers from Switzerland and France in 2011. Genton et al. (2011) noticed no significant changes in fat mass ( $\triangle 2008-1999 \mathrm{~F}:-0.4$ vs. M: 0.6) and fat free mass ( $\Delta 2008-1999$ F: -0.8 vs. M: -1.3$)$ in 112 subjects representing geriatric age during observations that lasted for 9 years [12].

Likewise, the present study suggests there are gender related differences in selected components of body composition. The females had significantly lower mean value of fat free mass, including cell and muscle mass and higher mean fat mass compared to the males. Similar findings were reported by Toomey et al (2015). These researchers found higher mean values of fat mass in women (F: $23.5 \mathrm{~kg}$ vs. M: 18.1 $\mathrm{kg}$ ) as well as lower values of fat free mass (F: 41.0 $\mathrm{kg}$ vs. M: $61.3 \mathrm{~kg}$ ) [3]. These findings are also supported by a recent study carried out by Australian researchers who examined a population of some 1929 individuals (aged 45-66) and identified lower mean values of fat free mass (F: $40.5 \mathrm{~kg}$ vs. M: $59.7 \mathrm{~kg}$ ) and higher mean values of fat mass (F: $30.4 \mathrm{~kg}$ vs. $24.9 \mathrm{~kg}$ ) in females [13].

The authors of this study concluded that there was a statistically significant difference between selected values of body composition and employment status of adults. The highest values of mean fat free mass, including cell and muscle mass, were identified in the currently employed individuals and the lowest values were reported in retired subjects. The latter also presented with the highest values of fat mass. A search for relevant reports, either consistent or conflicting with the present findings in the extensive full-text databases (EBSCO, Medline, Science 
Direct) showed no results containing a pairwise analysis of the body composition and employment status. In justifying the acquired results it can be assumed that the higher values of fat mass and lower of fat free mass are associated with the general trend for FM increase and FFM decrease with age which has been analysed at the initial stage of the discussion.

\section{CONCLUSIONS}

1. In the adult population, the higher one's age, the fat mass increases, while fat free mass decreases.

2. Females are reported to have lower mean values of fat free mass and its components and higher value of fat mass.

3. Employment status hugely affects the body composition in adults.

\section{FUNDING}

The material collected during the present study was processed as a part of the project Natural and Medical Innovation Research Centre carried out at the University of Rzeszów within the framework of 2007-2013 Regional Operational Programme of the Podkarpackie Region, agreement No. UDARPPK.01.03.00-18-004/12-00.

\section{REFERENCES}

1. Westerterp KR, Skowrońska-Piekarska U, Szczepanek K. Budowa organizmu In: L. Sobotka (ed). Podstawy żywienia klinicznego - edycja czwarta. Kraków: Scientifica; 2013.

2. Janiszewska R. Ocena składu ciała metodą bioelektrycznej impedancji u studentów o różnym stopniu aktywności fizycznej. MONZ. 2013;19(2):173-6

3. Toomey C, Leahy S, McCreesh K, et al. The body composition phenotype of Irish adults aged 18-81 years. Irish Journal of Medical Science, Ir J Med Sci. 2015;12. DOI 10.1007/s11845-015-1338-x

4. Małecka-Massalska T, Gołębiowski P, Chara K, et al. Wartości kąta fazowego mierzonego przy pomocy analizy impedancji bioelektrycznej u studentów Politechniki Lubelskiej. Zdr Publ. 2013;123(2):164-6.

5. Wolański N. Rozwój biologiczny człowieka. Warszawa: PWN; 2005.

6. Kyle UG, Bosaesus I, De Lorenzo AD, et al. Bioelectrical impedance analysis - part II: utilization in clinical practice. Clin Nutr. 2004;23:1430-53.

7. Nichols J, Going S, Loftin M, et al. Comparison of two bioelectrical impedance analysis instruments for determining body composition in adolescent girls. Int J Body Compos Res. 2006;4:153-60.

8. Dehghan M, Merchant AT. Is bioelectrical impedance accurate for use in large epidemiological studies? Nutr J. 2008;7:26.

9. Socha M, Karmińska K, Chwałczyńska A. Porównanie zawartości tkanki tłuszczowej u młodych nieotyłych kobiet i mężczyzn oznaczonej metodą bioimpedancji (wersja bi- i tetrapolarna) i metodą fotooptyczną. Endokrynol Otył Zab Przem Mat. 2010,6(1)18-25.

10. Lewitt A, Mądro E, Krupienicz A. Podstawy teoretyczne i zastosowania analizy impedancji bioelektrycznej (BIA). Endokrynol Otył Zab Przem Mat. 2007;3(4):79-84.

11. Sun SS, Chumlea WC, Heymsfield SB. et al. Development of bioelectrical impedance analysis prediction equations for body composition with the use of a multicomponent model for use in epidemiologic surveys. Am J Clin Nutr. 2003;77:331-40

12. Genton L, Karsegard VL, Chevalley T, et al. Body composition changes over 9 years in healthy elderly subjects and impact of physical activity. Clin Nutr. 2011;30(4):436-42.

13. Zhu K, Hunter M, James A, et al. Associations between body mass index, lean and fat body mass and bone mineral density in middle-aged Australians: The Busselton Healthy Ageing Study. Bone. 2015;74:146-52.

\section{Corresponding author}

Paweł Więch

Institute of Nursing and Health Sciences

2A Kopisto Avenue, 35-310 Rzeszów

Tel. +48667192696

E-mail: p.k.wiech@gmail.com 